\title{
Dropout School Children in Coastal Communities
}

\author{
Abdurrohman ${ }^{1 *}$, Nurun Sholeh ${ }^{2}$, Hanapi $^{3}$, and Baiq Liana Widiyanti ${ }^{4}$ \\ ${ }^{1,2,3}$ Dep. of Sociology Education, Faculty of Social Science and Economy, Universitas Hamzanwadi, Selong, \\ Indonesia, \\ ${ }^{4}$ Dept. of Environmental Engineering, faculty of Technology, Universitas Hamzanwadi, Selong, Indonesia. \\ "Corresponding author. Email: armindo.dmk@gmail.com
}

\begin{abstract}
Education by various groups is still believed to be an escalator to raise one's social status. Because of that education has a strategic position to break the path between poverty and ignorance. But this does not happen to coastal communities, remote on Gili Re. Where the number of children dropping out of school is very high. The majority of the final education of Gili Re coastal children only reaches primary school (SD) and not a few who drop out of school at the junior secondary level. The contributing factors are the lack of educational facilities, the economic conditions of parents and the views of parents and children on the importance of education. The purpose of this study was to determine dropout children on Gili Re and to find out the factors causing dropout children on Gili Re.
\end{abstract}

Keywords: children, coastal community, dropout school age

\section{INTRODUCTION}

Education by various groups is still believed to be an escalator to raise one's social status. Education is a strong milestone to overcome poverty of knowledge, solve the problem of ignorance, and solve all the problems of the nation that has been happening. Education is one of the efforts in order to improve the quality of human life. Basically, the purpose of education is to humanize human beings, mature human beings, change behavior, and improve human quality for the better. Therefore, education will support people's lives in the future (Moh, 2010).

According to the National Education System Law In order to educate the life of the nation, the government strives and organizes a national education system that is integrated, equitable, equal or balanced with local, regional and international quality bases. The aim is to improve the quality of Indonesia's human resources, catch up with all aspects of life and adapt to global changes and the development of science and technology ((Nomor, 2003.)

One of the problems of education that has not been able to be overcome until now is a dropout child ((Sabates et al., 2010; Schargel \& Smink, 2014)., et al., 2010). (Sabates et al., 2010; Schargel \& Smink, 2014). Dropping out of school is a predicate given to former students who are unable to complete an education level so they cannot continue their studies to the next level of education ((Rifa'i, 2016). Out of school children are those who have attended school at one level of education, but then cannot complete education due to various. From various research results found related to the dominant factors causing school dropouts including; parent attention factor ((Dewi et al., 2014). community view factor towards education ((Mujiati et al., 2018), play environment factor ((Laras, 2019). school distance factor ((Asmara \& Sukadana, 2016), parental employment factor as farm laborer, farmer, fisherman ((Sofya et al., 2018)

The government regulation on compulsory education is stipulated in article 34 of the National Education Law ((Indonesia, 2003). Stipulating that the government and regional governments guarantee the implementation of a compulsory education program at the minimum level of basic education without charging fees. Implementing the compulsory education basic education program is part of the education policy in Indonesia in achieving education for all. Regulations on compulsory education include the rights and obligations of Indonesian citizens, the responsibilities of the government and regional governments ((Umbara, 2017)

Ironically, the government regulation on compulsory education as stipulated in article 34 of the National Education Law in its implementation has not been fully even and fair. Poor people have not yet felt access to government policies in overcoming their fate. Their fate flows in the struggle of their own lives ((Oktari et al., 2015; Silfia, 2013).

This happened in the coastal and remote areas of Gili Re, Pare Mas Village, Jerowaru District. The education of children in these areas has not been fully considered by the government. This is a common irony faced by people in remote and outermost regions. In general, the educational problems often faced in remote 
areas are the lack of teacher staff, lack of representative learning space facilities and school locations that are difficult to reach, children's motivation and parents' attention is still low. Blurred portraits of children's education on Gili Re can be seen from the dropout rates. The majority of final education in the coastal communities of Gili Re is only up to elementary school (SD) and not a few who drop out of school at the junior high school level (SMP)

The blurry portrait of children's education on Gili $\mathrm{Re}$ has theoretical relevance in the perspective of Marx's conflict theory ((Coulthard et al., 2011; Fägerlind \& Saha, 2016; Grusky, 2019; Xie, 2019). According to the conflict theory that the main factor that causes social inequality is economic factors, then educational institutions also experience the same thing. This means that according to the perspective of conflict theory, educational institutions (schools) also contribute to causing social inequality in society. Schools are considered having widened the gap between the rich and the poor and education also helped the elite to maintain their dominance. Individuals from the upper classes will usually choose or continue their education to expensive and classy public schools. On the other hand, individuals from lower classes tend to continue their education in peripheral schools, lack quality, lack of facilities and even drop out of school due to lack of funds (Zainuddin, 2008).

Thus schools always create social inequalities in society, even though the education system provides the widest possible access, but this system will still not benefit the lower classes ((Martono, 2010; Usher \& Kober, 2012). This is what happens in remote areas such as Gili Re, Paremas Village.

Besides that, the low education of the coastal community of Gili Re also influences the mindset of parents of the importance of education. Even education is considered being part of the problems of their lives because it is considered burdening their economic conditions ((Mahmud, 2011; Wang et al., 2016). Based on the above, the authors are interested in researching related to school dropouts in the Coastal Communities in Gili Re, Paremas Village, Jerowaru District, East Lombok Regency.

\section{METHOD}

This research is a descriptive study with a qualitative approach. Qualitative approach is an approach in conducting research oriented to natural phenomena or phenomena ((Mahmud, 2011). The subjects of this study were students who had dropped out of school, parents and community leaders

Data collection techniques carried out by nonparticipant observation, in-depth interviews and documentation. While the data analysis uses the analysis of Miles \& Huberman ((Miles \& Huberman, 1992), namely the interactive model which classifies data analysis through three stages, namely data reduction, data presentation, and drawing conclusions.

\section{RESULTS AND DISCUSSION}

Common ceremony Low socioeconomic level is a common characteristic of fishermen's lives wherever they are ((Kusnadi, 2002; Wheeler et al., 2012). Generally this poverty condition is inherent in traditional fishermen who are more subsistence oriented ((Satria, 2015).

Unlike the people in the city who are so easy to access education, adequate infrastructure and the quality of qualified teachers. In remote areas, especially on Gili $\mathrm{Re}$, where the people earn a living as traditional fishermen, there are still many education problems that threaten the future of children. Fisherman's children on Gili Re must accept the reality of having a low level of education due to dropping out of school. In this context, the poverty that afflicts fishing households has made it difficult for them to shape the lives of the next generation better ((Laras, 2019).

It can be said that the future of children's education on Gili Re depends on the neighboring island, Gili Belek, because on Gili Re there are no school facilities at various levels. The size of the small area of Gili Re (91 hectares) 1 is the reason for not allowing him to build schools on the island. Most of the people of Gili Re, Paremas Village, only have education at the elementary school level and not a few of them have dropped out of school at the junior high school level.

Based on interviewed Gili Re's community education on average reaches elementary schools (SD) and junior high schools (SMP), only a few children who complete high school (SMA). Most of the children drop out of school on Gili Re when they sit in elementary school (SD) and junior high school (SMP).The following data on children's education in Gili $\mathrm{Re}$ Paremas Village:

Table 01 School Age Education on Gili Re

\begin{tabular}{|c|l|l|l|}
\hline No. & School Age Children & Total & Graduate \\
\hline 1 & Elementary school (SD) & 61 & 49 \\
\hline 2 & Junior High (SMP) & 38 & 24 \\
\hline 3 & High School (SMA) & 23 & 14 \\
\hline & total & 120 & 85 \\
\hline
\end{tabular}

Source: Profile of Desa Paremas, 2018 
Table 02 Dropout School Child on Gili Re

\begin{tabular}{|c|l|c|}
\hline No. & Dropout School Age & Total \\
\hline 1 & Elementary school (SD) & 12 \\
\hline 2 & Junior High (SMP) & 14 \\
\hline 3 & High School (SMA) & 9 \\
\hline & Total & 35 \\
\hline
\end{tabular}

Source: Profile of Desa Paremas, 2018.

Based on the informant's acknowledgment, that dropping out of school in the first grade of junior high school, because of economic limitations and the reality they encounter daily, is a barrier to continuing education and dropping out of school. The issue of school dropouts in Gili Re continues to occur from the past until now and still cannot be overcome until now. Therefore, education in Gili Re Paremas Village really requires government attention to resolve the factors causing high dropout rates on Gili Re. From the above data it can be explained that the number of school-age children on Gili Re is 120 people, who completed 85 people from elementary, junior high and high school levels. Whereas there are 35 dropouts from all levels of education. The highest number of children dropping out of school at the junior high school level is 14 people, while at the elementary school level there are 12 people and the high school level is 9 people.

\section{Factors Causing School Drop Outs}

From various studies, the factors that cause school dropouts are not only caused by one factor, but multi factors both internal and external factors ((Laras, 2019). The condition of school dropouts in the outermost and remote areas of Gili $\mathrm{Re}$ is also .y external and internal factors. However, there are three dominant factors that trigger high dropout rates on Gili Re.Based on the results of researchers searching through interviews from various parties there are several factors that cause children to drop out of high school, namely:

\section{a. Absence of educational facilities}

On Gili Re there are no educational facilities from elementary to high school. The only education facility available is PAUD. While PAUD did not last long and now no longer exists, because PAUD in Gili Re has not received written permission from the Regional Government. Because of the vast area of Gili Re which makes it impossible to build educational facilities so that the children of the coast of Gili Re have to take education to neighboring Gili, namely Gili Beleq. In other words, the future of children's education on Gili $\mathrm{Re}$ is determined in schools in Gili Beleq. Because SDSMAN facilities only exist on Gili Re, even then the children must go through access roads that are very alarming. One of the causes of school dropouts as acknowledged by the children above is the distance to the location of the school that must be traveled to neighboring Gili, namely Gili Beleq

\section{b. Economic Conditions of Parents}

Economic problems become a common problem inherent in coastal communities ((Coulthard et al., 2011; Viles \& Spencer, 2014). Inability of economic parents, many children do not attend school or drop out of primary school ((Kusnadi, 2002). This also happened to coastal children on Gili Re. Parents cannot afford to pay for their children to continue their education so they drop out of school. Children are required to join in earning a living bearing the burden of family life.

\section{c. Parent and Child Views of Education}

The education level of coastal communities on Gili Re which is generally low influences the mindset of parents on the importance of education. This is due to their view that even without highly educated children on Gili Re can already earn their own money by going to sea with their parents or neighbors. Besides that, if a child goes to school, it will be considered a burden on parents related to the cost

Based on the explanation above, it can be explained that parents' indifference to children's education on Gili Re affects the motivation of children to continue their education so that it will end in school dropouts. Therefore, there needs to be an awareness of various parties to provide input and related assistance related to the importance of education.

\section{CONCLUSIONS}

Children's Education in the Coastal Community of Gili Re is very worrying. Blurred portraits of education on Gili Re can be seen from the many children who drop out of school at the elementary and junior high levels. Besides that ,the future of children's education on Gili $\mathrm{Re}$ is very dependent on the neighboring island of Gili Belek

While the Causes of School Drop Outs on Gili Re are: first, the absence of educational facilities on Gili Re. Because the area is very small, it is not possible to build educational facilities so that the children of the Gili Re coast must study in the neighboring Gili, namely Gili Beleq. Second, the economic conditions of parents. The majority of the Gili Re community who work as fishermen with uncertain income becomes a consideration for children dropping out of school and parents supporting it Third, the views of parents and children towards education.he education level of coastal communities on Gili $\mathrm{Re}$ which is generally low influences the mindset of parents on the importance of education. This affects the motivation and learning 
interest of children is low so they prefer to drop out of schoo

\section{REFERENCES}

[1] Asmara, Y. R. I., \& Sukadana, I. W. (2016). Mengapa Angka Putus Sekolah Masih Tinggi?(Studi Kasus Kabupaten Buleleng Bali). EJ. EP Unud, 5(12), 1347-1383.

[2] Coulthard, S., Johnson, D., \& McGregor, J. A. (2011). Poverty, sustainability and human wellbeing: a social wellbeing approach to the global fisheries crisis. Global Environmental Change, 21(2), 453-463.

[3] Dewi, N. A. K., Zukhri, A., Dunia, I. K., \& Erg, M. (2014). Analisis faktor-faktor penyebab anak putus sekolah usia pendidikan dasar di Kecamatan Gerokgak tahun 2012/2013. Jurnal Pendidikan Ekonomi Undiksha, 4(1).

[4] Fägerlind, I., \& Saha, L. J. (2016). Education and national development: A comparative perspective. Elsevier.

[5] Grusky, D. (2019). Social Stratification, Class, Race, and Gender in Sociological Perspective. Routledge.

[6] Indonesia, R. (2003). Undang-Undang Nomor 20 Tahun 2003 tentang Sisdiknas. Jakarta: Kementrian Pendidikan Nasional.

[7] Kusnadi, M. A. (2002). Konflik Sosial Nelayan, Kemiskinan dan Perebutan Sumber Daya Perikanan. LKIS PELANGI AKSARA.

[8] Laras, P. B. (2019). STUDI EKSPLORASI PENYEBAB PUTUS SEKOLAH PADA SISWA-SISWI SEKOLAH DASAR DI DESA SRIMARTANI PIYUNGAN BANTUL YOGYAKARTA. Medikons: Jurnal Prodi Bimbingan Dan Konseling Unisri Surakarta, 5(1).

[9] Mahmud, H. (2011). Metode Penelitian Pendidikan. Bandung: CV Pustaka Setia.

[10] Martono, N. (2010). Pendidikan Bukan Tanpa Masalah: Mengurai Problematika Pendidikan dari Perspektif Sosiologi. Gava Media Yogyakarta.

[11] Miles, M. B., \& Huberman, A. M. (1992). Analisis Data Kualitatif. Terjemahan Tjetjep Rohendi Rohidi. Jakarta: Penerbit Universitas Indonesia.

[12] Moh, Y. (2010). Menggugat Pendidikan Indonesia. Ar-ruzz Media.

[13] Mujiati, M., Nasir, N., \& Ashari, A. (2018). Faktor-Faktor Penyebab Siswa Putus Sekolah. Didaktis: Jurnal Pendidikan Dan Ilmu Pengetahuan, 18(3).
[14] Nomor, U.-U. R. I. (20 C.E.). tahun 2003 tentang Sistem pendidikan Nasional.

[15] Oktari, R. S., Shiwaku, K., Munadi, K., \& Shaw, R. (2015). A conceptual model of a school-community collaborative network in enhancing coastal community resilience in Banda Aceh, Indonesia. International Journal of Disaster Risk Reduction, 12, 300-310.

[16] Rifa'i, M. (2016). Sosiologi Pendidikan. ArRuzz Media.

[17] Sabates, R., Westbrook, J., Akyeampong, K., \& Hunt, F. (2010). School drop out: Patterns, causes, changes and policies.

[18] Satria, A. (2015). Pengantar sosiologi masyarakat pesisir. Yayasan Pustaka Obor Indonesia.

[19] Schargel, F. P., \& Smink, J. (2014). Strategies to help solve our school dropout problem. Routledge.

[20]Silfia, H. (2013). Sosiologi Pendidikan Keindonesiaan. Ar-Ruzz media.

[21] Sofya, R., Siwi, M. K., \& Oknaryana, O. (2018). Kondisi Sosial Ekonomi Siswa Putus Sekolah. Jurnal Inovasi Pendidikan Ekonomi, 8(2), 90-94.

[22] Umbara, U. (2017). Psikologi Pembelajaran Matematika (Melaksanakan Pembelajaran Matematika Berdasarkan Tinjauan Psikologi). Deepublish.

[23] Usher, A., \& Kober, N. (2012). 4. What Roles Do Parent Involvement, Family Background, and Culture Play in Student Motivation? Center on Education Policy.

[24] Viles, H., \& Spencer, T. (2014). Coastal problems: geomorphology, ecology and society at the coast. Routledge.

[25] Wang, Y., Deng, C., \& Yang, X. (2016). Family economic status and parental involvement: Influences of parental expectation and perceived barriers. School Psychology International, 37(5), 536-553.

[26] Wheeler, B. W., White, M., Stahl-Timmins, W., \& Depledge, M. H. (2012). Does living by the coast improve health and wellbeing? Health \& Place, 18(5), 1198-1201.

[27]Xie, Y. (2019). Study on Rural Ecological Environment Protection from the Perspective of Marxist Interest Theory. 2nd International Conference on Economy, Management and Entrepreneurship (ICOEME 2019).

[28]Zainuddin, M. (2008). Sosiologi Pendidikan. Yogyakarta: GadjahMada University Press. 